Nina Ogińska-Bulik

Instytut Psychologii UŁ

\title{
Kiedy lzy zamieniają się w perły \\ - czyli o korzyściach wynikających ze zmagania się z traumą
}

\section{Potraumatyczny rozwój}

Doświadczanie wydarzeń traumatycznych pociaga za sobą różnego rodzaju konsekwencje, zarówno negatywne (np. objawy zespołu stresu pourazowaego), jak i pozytywne. Te pozytywne zmiany to inaczej zjawisko potraumatycznego rozwoju (Tedeschi, Calhoun, 1996). Pojęcie to nawiązuje do wcześniejszych poglądów G. Caplana czy E. Frankla, kontynuowanych przez K. P o p i e 1 skiego (2009), którzy wskazywali, że doświadczanie silnie stresujących wydarzeń, będących źródłem cierpienia, może wiązać się nie tylko z negatywnymi następstwami, ale także z pojawieniem się pozytywnych zmian psychologicznych.

W odniesieniu do rozwoju po traumie używa się też innych pojęć, takich jak: znajdowanie korzyści (benefit finding), wzrost związany ze stresem (stress-related growth), transformacyjne radzenie sobie (transformative coping), rozkwit/rozkwitanie (thriving/flourishing) czy rozwój wynikający z przeciwności (adversarial growth) (T e d e s c h i, C a l h o u n, 2007).

R. T e de s ch i i L. C al h o un (1996), odwołując się do podejścia egzystencjalnego, zakładaja, że rozwój zachodzi w sytuacji, gdy u człowieka następują zmiany w sposobie widzenia siebie i świata, polegające na ich głębszym rozumieniu i nadaniu znaczenia. W efekcie doświadczona strata, poprzez doznanie cierpienia, zostaje przekształcona w istotną dla człowieka wartość. Co więcej, to pogłębione rozumienie siebie i otaczającej rzeczywistości pozwala człowiekowi na bardziej skuteczne radzenie sobie z przeciwnościami losu w przyszłości.

Mechanizm zmian rozwojowych po wydarzeniu traumatycznym związany jest bezpośrednio z procesami poznawczego przepracowania informacji dotyczących doświadczonej sytuacji, odbudowy schematów poznawczych, poszukiwania sensu wydarzenia i jego znaczenia dla dalszego funkcjonowania człowie$\mathrm{ka}^{1}$ (Tedeschi, Calhoun, 1996, 2007). Podobnie S. Joseph i R. Wil -

${ }^{1}$ Proces rozwoju potraumatycznego został także opisany w literaturze polskiej $\mathrm{m}$. in. w: O g i ń s k a-B u li k, 2010a, b, c; O g ińs k a-B u li k, J u c z y ń s k i, 2010a, b. 
li a ms (2005) utożsamiają potraumatyczny rozwój z dokonującymi się zmianami w systemie poznawczym człowieka. Zmiany te służą przystosowaniu wiedzy do realności, w której występują zdarzenia krytyczne. Następuje tu więc proces akomodacji, którego skutkiem jest powstanie nowych schematów, uwzględniających bardziej pozytywne założenia dotyczące otaczającej rzeczywistości.

Potraumatyczny rozwój jest czymś więcej niż tylko powrotem do stanu równowagi po doświadczonym przeżyciu traumatycznym. Zjawisko to wskazuje, że jednostka w wyniku traumy przechodzi pewnego rodzaju transformację i uzyskuje wyższy niż przed traumą poziom funkcjonowania, wyrażający się $\mathrm{m}$. in. w wyższym poczuciu dobrostanu i większej świadomości życiowej. Potraumatyczny wzrost nie oznacza także, że samo przeżycie traumy jest czymś dobrym, pożądanym lub koniecznym dla rozwoju czy dokonania zmiany. R. Te de s ch i i L. C a lh o u n (2007) zakładaja, że potraumatyczny rozwój jest nie tyle efektem przeżytej traumy, co podejmowanych w jej wyniku strategii zaradczych. Inni autorzy (Z o e ll ner, Ma e r cker, 2006) traktuja potraumatyczny rozwój jako proces radzenia sobie $\mathrm{z}$ traumatycznymi wydarzeniami. Z kolei V. O'L e a ry (1998) określa zmiany po traumie jako dynamiczny proces mobilizacji zasobów w odpowiedzi na pojawiające się zagrożenie, co zbliża to pojęcie do terminu ,prężność” (resilience).

Nieco szersze spojrzenie na zagadnienie rozwoju po traumie prezentuja V. Helgeson i in. (2006). Według wymienionych autorów jest to zespół procesów obejmujących aktualne zmiany życiowe człowieka, wykorzystywane sposoby radzenia sobie, a także poznawcze manipulacje. Te ostatnie nawiązują do znanej w psychologii zdrowia teorii adaptacji poznawczej J. Taylor (por. Ogińska-Bulik, Juczyński, 2010a). Teoria ta zakłada, że osoby doświadczające negatywnego wydarzenia życiowego, jakim była choroba nowotworowa, wykorzystują pozytywne iluzje, stosowane jako sposób radzenia sobie z sytuacją. Iluzje te pozwalają na utrzymanie dobrostanu pomimo doświadczania choroby.

Pozytywne zmiany, składające się na potraumatyczny rozwój, jak podkreślają R. Tedeschi i L. Calhoun (1996), obejmują zmiany w relacjach interpersonalnych, percepcji siebie i zmiany w filozofii życiowej. Niektóre osoby, które przeżyły traumę, nawiązują bliższe relacje z innymi, odkrywają w sobie większe pokłady wrażliwości i współczucia dla innych. Wykazują też większą skłonność do otwierania się przed innymi i lepiej się czują w tych relacjach. Ludzie pod wpływem traumatycznego doświadczenia odnajdują w sobie siłę, która pozwala im z dystansem przyjrzeć się dotychczasowemu życiu i zmieniać je na lepsze.

Osoby doświadczające potraumatycznego wzrostu w wyniku przeżytych sytuacji traumatycznych w większym stopniu przywiązują wagę do drobnych codziennych wydarzeń, a zdają się pomniejszać znaczenie ważnych spraw życiowych. Rodzina, przyjaciele, a także drobne przyjemności codziennego dnia 
mogą być postrzegane jako ważniejsze od tych, które wcześniej traktowane były jako pierwszoplanowe (np. kariera zawodowa). W wyniku poradzenia sobie z krytycznym wydarzeniem jednostka może przejawiać zwiększone poczucie osobistej siły, przekonanie o własnej skuteczności, większe zaufanie do siebie i własnych możliwości także w odniesieniu do przyszłych wydarzeń. Osoby takie zauważają swoje zwiększone umiejętności radzenia sobie i przetrwania w skrajnie trudnych warunkach, dostrzegają nowe możliwości w życiu i stawiają sobie nowe cele. Doświadczanie traumy może także zaowocować zmianami w przekonaniach egzystencjalnych (religijnych) jednostki. Osoby, które doświadczyły traumatycznej sytuacji, bardziej doceniają życie i przeżywają je bardziej świadomie. R. Te de s chi i L. Ca lhoun (2007) zwracają uwage, że filozofia życiowa ludzi, którzy uporali się z kryzysem, staje się bardziej dojrzała, znacząca i satysfakcjonująca.

\section{Rozpowszechnienie}

Występowanie pozytywnych zmian w wyniku przeżytej traumy jest dość powszechne, choć potraumatyczny rozwój nie jest doświadczeniem uniwersalnym. Dane co do rozpowszechnienia zjawiska, przytaczane przez autorów, różnią się dość znacznie: od 3\% osób w żałobie (D a vi e s i in., 1998) do 98\% u kobiet z rakiem piersi (We is s, 2002). Z badań J. Campbella (2007) wynika, że ponad połowa badanych, którzy przeżyli wyjątkowo trudne wydarzenie, stwierdziła, że miało ono pozytywny wpływ na ich życie. Większość badaczy przyjmuje, że potraumatyczny rozwój występuje u $30-90 \%$ ludzi (M y s takid ou i in., 2008; Te d e s ch i, Cal houn, 1996; T e o i in., 2007).

Odsetek osób doświadczających rozwoju po traumie przypuszczalnie wiąże się z rodzajem doświadczonego wydarzenia. Występowanie pozytywnych zmian po traumie stwierdzono u $80 \%$ osób, które przeżyły śmierć bliskiej osoby (Davis, Nolen-Hoeksema, 2001), 55\% ofiar katastrofy lotniczej, 76\% ocalałych ze strzelaniny (Te nne n, Affle ck, 2002). Potraumatyczny rozwój zanotowano dla wysokiego odsetka (do 83\%) zarażonych wirusem HIV i chorych na AIDS w okresie następującym po diagnozie (Mila m, 2004). W polskich badaniach kobiet chorych onkologicznie po zabiegu resekcji piersi (O g i ń s k a-B u li k, 2010a) wysokie nasilenie pozytywnych zmian zanotowano u $50 \%$ badanych (po $25 \%$ ujawniło niski i przeciętny poziom potraumatycznego rozwoju). $Z$ kolei $w$ badaniach młodzieży doświadczającej różnych wydarzeń o charakterze traumatycznym (Ogińska-Bulik, 2010b) wysokie nasilenie pozytywnych zmian zaobserwowano u $22,5 \%$ badanych $(41,7 \%$ określiło poziom zmian jako przeciętny, a 35,8\% - jako niski).

Zjawisko to notowane jest także u dzieci. 50\% dzieci, które doświadczyły traumy w związku z huraganem Katrina w Stanach Zjednoczonych ujawniło 
wysoki stopień zmian, a 7,5\% - mniejszy. U pozostałych zanotowano zmiany minimalne lub ich brak. Co więcej, pozytywne zmiany utrzymywały się po upływie 2 lat od wydarzenia (Kil m er i in., 2009).

\section{Czynniki warunkujące potraumatyczny rozwój}

Zjawisko potraumatycznego rozwoju jest efektem współwystępowania wielu czynników. Ich charakterystykę przedstawiono poniżej.

\subsection{Rodzaj i intensywność doświadczanej traumy}

Wśród różnych uwarunkowań pozytywnych zmian po traumie uwzględnia się przede wszystkim rodzaj doświadczonego wydarzenia traumatycznego, jego intensywność $\mathrm{i}$ związany $\mathrm{z}$ nimi stopień zagrożenia dla zdrowia lub życia. Z dokonanego przeglądu badań (L i n le y, J o s e p h, 2004) wynika, że najwyższe nasilenie pozytywnych zmian uzyskały kobiety, które były w żałobie po stracie dziecka, najniższe zaś zanotowano u mężczyzn, których żony chorowały na nowotwór piersi. Polskie badania także wskazują na zróżnicowany poziom potraumatycznego rozwoju w zależności od rodzaju traumy. Najwyższy zaobserwowano u matek dzieci chorych na leukemię i rodziców opiekujących się dziećmi z zespołem Downa, najniższy - u żołnierzy uczestniczących w misjach pokojowych poza granicami kraju, strażaków i policjantów, którzy doświadczają wydarzeń traumatycznych w miejscu pracy (O gińska-Bulik, Juczyński, 2010b). Może to oznaczać, że zmaganie się $\mathrm{z}$ wydarzeniem traumatycznym związanym z nieustanną opieką nad chorymi skutkuje większymi pozytywnymi zmianami niż doświadczanie wydarzeń traumatycznych niejako wpisanych w wykonywanie zawodu. Sugeruje także, że wydarzenie zaskakujące i nieprzewidywalne (choroba dziecka) prowadzi do szybszego wzrostu niż wydarzenie, które osoba, podejmująca pracę strażaka czy policjanta, może przewidzieć i na wystapienie którego jest (a przynajmniej powinna być) przygotowana. Analizując powyższe zależności, nie można wykluczyć wpływu płci na rozwój potraumatyczny. Dostępne w tym zakresie dane wskazują bowiem, że większą zdolność do czerpania korzyści z traumy wykazują kobiety (Tedeschi, Cal h o u n, 1996; W e is s, 2002; O g i ń s k a-B u li k, J u c z yń s ki, 2010a, b).

Istotne znaczenie dla wystapienia potraumatycznego rozwoju przypisuje się intensywności samego wydarzenia traumatycznego. Im bardziej intensywna trauma, tym większa szansa na wystapienie pozytywnych zmian w jej wyniku (McMillen i in., 2001; Park i in., 1996). Jednakże niektórzy autorzy (Calhoun, Tedeschi, 1999; A. Fontana, R. Rosenheck, za: Linley, J o s eph, 2004) podkreślają, że jest to raczej zależność krzywoliniowa, co oznacza, że wydarzenie o małej, ale i skrajnie dużej intensywności, nie sprzyja 
pojawieniu się potraumatycznego rozwoju. Natomiast trauma o umiarkowanej i wysokiej sile zwiększa prawdopodobieństwo jej przepracowania, a co za tym idzie - wystapienia pozytywnych zmian w postaci potraumatycznego rozwoju. Zdają się to potwierdzać badania chorych onkologicznie, obejmujące grupe kobiet i mężczyzn, w których wykazano, że najwyższy poziom potraumatycznego wzrostu wystąpił u pacjentów znajdujących się w II lub III stadium zaawansowania choroby, natomiast u pacjentów w I i IV stadium raka jego natężenie było istotnie niższe (L e chner i in., 2003). Podobna zależność odnosi się do przejawianych negatywnych symptomów choroby: słabe i bardzo silne wiązały się $\mathrm{z}$ niższym nasileniem wzrostu, podczas gdy umiarkowane $-\mathrm{z}$ wyższym jego poziomem. Powaga choroby i towarzyszące jej emocje, przede wszystkim w postaci lęku, ale o umiarkowanej sile, zdają się sprzyjać przepracowaniu traumy, co pociagga za sobą pozytywne zmiany, zwłaszcza w zakresie większego doceniania życia.

Proces potraumatycznego rozwoju nie wyklucza więc występowania stanu dystresu i obniżenia poczucia dyskomfortu. Ich wystapienie wydaje się wręcz konieczne w celu przystosowania się do nowych okoliczności. Doświadczenia potraumatycznego rozwoju i psychicznego dystresu, jak twierdzą R. T e d e s c h i i L. Cal h o u n (2007), stanowią zasadniczo odrębne wymiary. Może to oznaczać, że jednostki doświadczające wzrostu moga jednocześnie przejawiać stan dystresu i obniżonego poczucia dobrostanu. Zdają się to potwierdzać wyniki badań przeprowadzonych przez V. Helges on i in. (2006), wskazujące na pozytywny związek potraumatycznego wzrostu z niektórymi objawami PTSD, tj. intruzją i unikaniem negatywnych myśli, związanych $\mathrm{z}$ doświadczanym wydarzeniem traumatycznym. Pozytywną zależność między obecnością zaburzeń adaptacyjnych, będących skutkiem zdarzenia traumatycznego, a występowaniem oznak rozwojowych stwierdzono także w grupie żołnierzy uwięzionych w trakcie działań wojennych (S a l o m o n, D e k e l, 2007) oraz żołnierzy uczest niczących w misjach wojskowych (Załuski, 2008). Podobnie w badaniach własnych (Ogińska-B u lik, J u c zyński, 2010b) zaobserwowano dodatnią korelację między objawami stresu pourazowego (mierzonymi Skalą Wpływu Zdarzeń), obejmującymi intruzję, pobudzenie i unikanie, a potraumatycznym wzrostem. Potwierdza to tezę, iż negatywne skutki doświadczanej traumy mogą współwystępować z pozytywnymi zmianami, odnoszącymi się do różnych aspektów funkcjonowania człowieka.

Nie bez znaczenia dla wystapienia zjawiska potraumatycznego rozwoju jest czas, jaki upłynął od wystapienia wydarzenia traumatycznego. R. T e de s chi i L. Calhoun $(1998,2007)$ zauważyli, że najwięcej pozytywnych zmian występuje w okresie od dwóch tygodni do dwóch miesięcy po przeżytym wydarzeniu, ale podkreślają, że potraumatyczny rozwój może mieć miejsce również wiele lat po traumie. $Z$ kolei inni badacze (Cordova i in., 2001; Evers i in., 2001; P a r k i in., 1996) wskazują, że im dłuższy czas od wydarze- 
nia, tym większe nasilenie pozytywnych zmian. Jeszcze inne badania (Mila m i in., 2004) dostarczają danych sugerujących, że nie ma związku między czasem, jakim upłynął od krytycznego wydarzenia, a wystapieniem potraumatycznego rozwoju.

Niewiele jest danych na temat stabilności pozytywnych zmian, które pojawiły się $w$ następstwie traumatycznego wydarzenia. $Z$ przeglądu badań (L i n ley, Joseph, 2004) wynika, że pozytywne zmiany, które pojawiły się po traumie, są utrzymywane przez dłuższy czas, nawet powyżej 8 lat. Znaczący wzrost nasilenia pozytywnych zmian wraz $\mathrm{z}$ upływem czasu zaobserwowano w zakresie filozofii życiowej, priorytetów i duchowości. Z kolei relacje z innymi nieco osłabły. Utrzymywanie się pozytywnych zmian po traumie po wielu latach od wydarzenia traumatycznego potwierdzają badania polskie przeprowadzone na grupie kobiet chorych onkologicznie po zabiegu mastektomii (Ogińska- Bulik, 2010a).

\subsection{Czynniki socjodemograficzne}

Przegląd badań w obszarze socjodemograficznych uwarunkowań potraumatycznego rozwoju wskazuje przede wszystkim na znaczenie płci. Kobiety zdają się doświadczać więcej pozytywnych zmian w wyniku doświadczenia sytuacji traumatycznych w porównaniu z mężczyznami (T e d e s c hi, C a l h o u n, 1996; W e is s, 2002; O gińska-Bu lik, Ju czyński, 2010a, b). Może to wynikać $\mathrm{m}$. in. z faktu, iż kobiety częściej stosują korzystne z punktu widzenia wystąpienia zjawiska strategie radzenia sobie ze stresem, takie jak pozytywne przewartościowanie, poszukiwanie wsparcia emocjonalnego, samoekspresja emocji. Jednakże są też badania wskazujące, że płeć nie różnicuje nasilenia potraumatycznego rozwoju (Milam i in., 2004; Polatynsky, Esprey, 2000), ale zwraca się w nich uwagę na mała liczebność osób badanych. Jeszcze inni badacze zwracają uwagę, że płeć może różnicować nasilenie niektórych obszarów potraumatycznego rozwoju. Zdają się na to wskazywać badania przeprowadzone na grupie chorych onkologicznie, w których zaobserwowano, że u kobiet, w porównaniu z mężczyznami, wystąpiły większe zmiany duchowe (S te e 1 i in., 2008).

Brak jest jednoznacznych danych dotyczących roli wieku w rozwoju potraumatycznym. V. Helges on i in. (2006) wskazują, że wyższy poziom potraumatycznego rozwoju charakteryzuje ludzi młodszych. Mniejsze nasilenie pozytywnych zmian u osób starszych zaobserwowali także C. Davis i in. (1998). Autorzy wiążą to z faktem zbliżającej się śmierci. Wśród nastolatków więcej pozytywnych zmian zaobserwowano w grupie starszych (Mila m i in., 2004).

Związek między wiekiem a nasileniem pozytywnych zmian po traumie analizowano także $w$ badaniach polskich (Ogińska-Bulik, Juczyński, 
2010b). Uwzględniając okresy rozwojowe (okres dorastania, wczesnej, średniej i późnej dorosłości), nie zanotowano różnic istotnych statystycznie w zakresie ogólnego wskaźnika potraumatycznego rozwoju ( $M$ odpowiednio równe: 60,86; $60,64 ; 62,11 ; 62,78 ; F=0,356)$, jak i jego czynników. Przy podziale grupy na młodszych i starszych (na podstawie średniej wieku) nie ujawniono istotnych różnic w zakresie ogólnego wskaźnika potraumatycznego rozwoju, jednakże zaznaczyły się pewne różnice w zakresie poszczególnych czynników. Osoby starsze (powyżej 35. roku życia), w porównaniu z młodszymi, ujawniły więcej pozytywnych zmian $\mathrm{w}$ zakresie relacji $\mathrm{z}$ innymi $(p<0,01)$ oraz $\mathrm{w}$ sferze duchowej $(p<0,02)$. Uwzględniając oddzielnie grupę nastolatków daje się zauważyć, że nasilenie pozytywnych zmian po traumie jest u nich wyraźnie niższe $(M=52,98 S D=23,21)$ w porównaniu $\mathrm{z}$ dorosłymi $(M=61,62$; $S D=19,3)($ O gińska-Bulik, 2010b). Analizując oddzielnie wyniki adolescentów (14-18 lat) nie wykazano istotnych różnic w nasileniu pozytywnych zmian po traumie w zależności od wieku badanych (O g iń s k a-B u lik, 2010b). Na podstawie dotychczasowych danych można stwierdzić, że występowanie zjawiska rozwoju po traumie nie podlega wyraźnym zmianom w cyklu życia.

Status ekonomiczny oraz stan cywilny zdają się nie wpływać na nasilenie potraumatycznego rozwoju, choć są badania wskazujące, że wyższe wykształcenie i wyższe dochody wiążą się z większymi zmianami po traumie (L in ley, Jo s e p h, 2004).

\subsection{Radzenie sobie ze stresem}

Niewątpliwie ważnym czynnikiem związanym z wystapieniem potraumatycznego rozwoju są strategie radzenia sobie, wykorzystywane w procesie zmagania się $\mathrm{z}$ negatywnymi wydarzeniami życiowymi. R. Tedeschi i L. Calhoun (2007) wskazują wyraźnie, że potraumatyczny rozwój jest efektem przeżytej traumy, ale to nie sama trauma przyczynia się do wystapienia wzrostu, lecz stosowane przez jednostkę strategie zaradcze. Wśród strategii radzenia sobie ze stresem sprzyjających wystapieniu pozytywnych zmian po traumie wymienia się akceptację, pozytywne przewartościowanie, radzenie sobie skoncentrowane na zadaniu i oparte na religii (L in ley, Joseph, 2004). Najwięcej danych na temat roli sposobów radzenia sobie w potraumatycznym rozwoju dostarczają badania prowadzone na osobach zmagających się z chorobą.

Wystapieniu pozytywnych zmian w wyniku doświadczenia traumatycznego, jakim jest choroba nowotworowa, sprzyja aktywne radzenie sobie (dotyczy to przede wszystkim osób wyraźnie nastawionych na walkę z choroba), pozytywne przewartościowanie czy poczucie humoru, a także poszukiwanie wsparcia społecznego (M orris i in., 2007), choć jego rola nie wydaje się tak znacząca, jak by należało się tego spodziewać. 
W badaniach mających na celu sprawdzenie związku przystosowania się do choroby z potraumatycznym rozwojem (Lechner i in., 2003) dowiedziono, że był on pozytywnie związany ze strategią ducha walki - traktowaną jako najbardziej przystosowawcza $\mathrm{w}$ procesie zmagania się $\mathrm{z}$ chorobą natomiast strategia bezradności/beznadziejności wiązała się z nim negatywnie. $\mathrm{W}$ innych badaniach przeprowadzonych na kobietach $\mathrm{z}$ rakiem piersi zanotowano, że potraumatyczny rozwój w okresie diagnozy i leczenia choroby był pozytywnie związany $\mathrm{z}$ radzeniem sobie opartym na religii, odwracaniu uwagi, $z$ pozytywnym przewartościowaniem i mniejszym poszukiwaniem wsparcia społecznego. W późniejszym okresie (3 miesiące od operacji) z potraumatycznym rozwojem wiązało się przede wszystkim aktywne radzenie sobie i radzenie sobie oparte na religii. $Z$ kolei 6 miesięcy później wzrost był związany z aktywnym radzeniem sobie, radzeniem sobie opartym na emocjach, większym poszukiwaniem wsparcia społecznego, radzeniem sobie opartym na religii i mniejszym stopniem radzenia sobie związanego z akceptacją zaistniałej sytuacji. Rok po operacji istotne znaczenie dla potraumatycznego rozwoju odgrywały pozytywne przewartościowanie i strategia planowania (L e c h ner, A n t on i, 2004).

Znaczenie różnych strategii radzenia sobie z chorobą w zależności od czasu choroby ujawniono także $\mathrm{w}$ innych badaniach, obejmujących grupę kobiet z rakiem piersi (B ussell, Naus, 2010). Predyktorem potraumatycznego rozwoju w okresie leczenia (za pomocą chemioterapii) było radzenie sobie oparte na religii. W okresie późniejszym istotne znaczenie dla wystapienia wzrostu miały strategie pozytywnego przewartościowania oraz poszukiwanie wsparcia zarówno instrumentalnego, jak i emocjonalnego. Wynika to z faktu, że proces radzenia sobie $z$ chorobą ma charakter dynamiczny i że poziom potraumatycznego rozwoju wiąże się z różnymi strategiami radzenia sobie, których stosowanie zależy od czasu trwania choroby.

$\mathrm{W}$ procesie radzenia sobie z negatywnymi wydarzeniami życiowymi istotną rolę pełni religijne (duchowe) radzenie sobie. Ludzie, zwłaszcza starsi, u których rozwinęła się duchowość, lepiej sobie z nimi radzą (L i n le y, Jo s e p h, 2004). Wiąże się to $\mathrm{m}$. in. z uznaniem własnej kruchości, przemijalności czy akceptacją śmiertelności. Na znaczenie duchowości w zmaganiu się ze stresem zwraca uwagę I. Heszen (2010). Warto podkreślić, iż w procesie pojawiania się korzystnych zmian po traumie szczególne znaczenie przypisuje się przede wszystkim strategiom emocjonalno-unikowym. Natomiast strategie skoncentrowane na problemie zdają się nabierać znaczenia dopiero na dalszych etapach poprawy dobrostanu.

$\mathrm{W}$ ostatnich latach $\mathrm{w}$ procesie zmagania się $\mathrm{z}$ negatywnymi wydarzeniami życiowymi podkreśla się rolę radzenia sobie skoncentrowanego na znaczeniu (Heszen, Sęk，2007; Heszen，2010; Og ińska-Bulik，Juczyński, 
2010a). Radzenie to, prowadząc do znajdowania sensu doświadczanych wydarzeń, pełni funkcję adaptacyjną. Umożliwia poznawcze przetwarzanie krytycznego wydarzenia oraz sprzyja wyzwalaniu emocji pozytywnych, a to zwiększa prawdopodobieństwo pojawienia się korzyści z traumy.

\subsection{Wsparcie spoleczne}

Czynnikiem, który zwiększa prawdopodobieństwo wystąpienia potraumatycznego rozwoju jest dostępność wsparcia społecznego. Szczególnie ważne wydaje się tu wsparcie emocjonalne. Możliwość wyjawiania myśli, ekspresji emocji, dzielenie się odczuciami sprzyjają przepracowaniu traumy i zwiększa szanse na potraumatyczny rozwój (T edeschi, Calhoun, 1996, 2007). Pośrednim dowodem na znaczenie wsparcia społecznego może być związek nasilenia pozytywnych zmian po traumie ze stylem przywiąania. Badania przeprowadzone na grupie torturowanych mężczyzn (S a lo i in., 2005) wskazały, że ci z bezpiecznym stylem przywiązania wykazywali wyższy poziom potraumatycznego rozwoju, przejawiający się zmianami w zakresie osobistej siły, zmian duchowych i bliskości z innymi, w porównaniu z mężczyznami, dla których charakterystyczny był ambiwalentny i unikowy styl przywiązania. Sugeruje to, że dobre i mądre rodzicielstwo może sprzyjać formowaniu się u dzieci pozytywnych schematów dotyczących sensowności świata, życzliwości dla innych, a także poczucia własnej wartości.

W procesie skutecznego poradzenia sobie z traumą, które może zaowocować wystąpieniem pozytywnych zmian, ważniejszą rolę niż sama dostępność wsparcia zdaje się odgrywać spostrzegane wsparcie społeczne, czyli to, czy jednostka dostrzega w swoim otoczeniu osoby, które moga jej udzielić pomocy w sytuacji kryzysu. Poszukiwanie wsparcia zarówno instrumentalnego, jak i emocjonalnego jest powiązane przede wszystkim $\mathrm{z}$ dostrzeganiem nowych możliwości w życiu i poprawą relacji z innymi. Wsparcie społeczne stwarza możliwość ekspresji negatywnych emocji i otrzymania praktycznej pomocy, co może wspomagać przetwarzanie poznawcze zdarzenia i ułatwiać przepracowanie traumy.

Poszukiwanie wsparcia społecznego okazało się istotnie związane z wystąpieniem pozytywnych zmian po traumie u pacjentów chorych onkologicznie (M orris i in., 2007). Jednakże są także badania niepotwierdzające znaczenia wsparcia społecznego (J. McMillen, za: L in 1 e y, J o s e p h, 2004). P. L in l e y i S. J o s e p h (2004) podkreślają że dla doświadczających traumy ważne jest nie samo wsparcie jako takie, co raczej satysfakcja $\mathrm{z}$ otrzymywanego wsparcia społecznego. 


\subsection{Zasoby osobiste}

Zasoby osobiste obejmują zarówno cechy osobowości człowieka, jak i jego oczekiwania oraz przekonania, dotyczące samego siebie i świata zewnętrznego. Wymienić tu należy odporność psychiczną i zintegrowaną osobowość. Im bardziej zintegrowana osobowość, jak podkreślają R. C a r s o n i in. (2003), tym większe szanse na poradzenie sobie z traumą. Istotne znaczenie ma także sposób funkcjonowania poznawczego, a przede wszystkim umiejętność odnajdowania sensu w kryzysie i nadawania znaczenia cierpieniu. Im wyższe poczucie sensu życia, tym sprawniej jednostka obchodzi się z doświadczeniem cierpienia (P o p i elski, 2009). Świadczą o tym badania australijskie przeprowadzone na grupie chorych onkologicznie po diagnozie raka, które pokazuja, iż przekonania dotyczące sprawiedliwości świata i szczęścia były pozytywnie związane z potraumatycznym wzrostem (C a r b o o $\mathrm{n}$ i in., 2005).

Z pozytywnymi zmianami po traumie dodatnio korelują cztery cechy składające się na model osobowości Wielkiej Piątki, tj. otwartość na doświadczenia, ekstrawersja, ugodowość i sumienność, natomiast w odniesieniu do neurotyczności zależność miała charakter ujemny (L i n l e y, J o s e p h, 2004).

Istotne znaczenie dla wystąpienia pozytywnych zmian po traumie zdają się odgrywać przeżywane emocje. Dodatnią korelację afektu pozytywnego (i ujemną afektu negatywnego) z potraumatycznym rozwojem stwierdzili w swoich badaniach A. Ever s i in. (2001). Z kolei osoby lękowe i cierpiące na depresję są mniej skłonne do doznawania korzyści wynikających z wydarzeń traumatycznych (Linley, Jos e ph, 2004). Jest rzeczą oczywistą, że osoba, która doświadczyła sytuacji traumatycznej, przeżywa stan silnego dystresu i negatywne emocje często o dużej sile. Nie wyklucza to jednak zdolności do odczuwania afektu pozytywnego, cieszenia się drobnymi wydarzeniami. Zdolność doświadczania emocji pozytywnych z jednej strony zwiększa zdolność do tolerowania emocji negatywnych, a $z$ drugiej - pozwala człowiekowi na większą elastyczność, kreatywność; zwiększa zdolność do integrowania informacji, a to z kolei ułatwia przepracowanie traumy. Na znaczenie emocji pozytywnych w obliczu stresu życiowego zwracała uwagę B. F re d r i c k s o n (2001) w swojej teorii budowania i rozszerzania pozytywnych emocji (Broaden and Build Theory of Positive Emotions). Autorka podkreśla, że emocje pozytywne nie tylko pozwalają na bardziej skuteczne radzenie sobie $\mathrm{z}$ negatywnymi wydarzeniami, ale także przyczyniają się do budowania zasobów, które mogą być wykorzystywane w przyszłości. Badania A. Is e n (2005) potwierdziły, że pozytywne emocje służą przepracowaniu traumy, a co za tym idzie - sprzyjają dostrzeżeniu korzyści będących jej wynikiem.

Podobnie istotną rolę w przepracowaniu traumy pełni zdolność do wyrażania emocji. Dzielenie się przeżyciami, ujawnianie emocji z nimi związanych sprzyjają wentylowaniu emocji i przetwarzaniu dotychczasowych schematów 
poznawczych (P e n n e b a ker, 2001). Sprzyjającymi wystapieniu pozytywnych zmian w wyniku doświadczenia wydarzenia traumatycznego są także nadzieja, dyspozycyjny optymizm, poczucie koherencji, własnej wartości, skuteczności, wysokie poczucie zadowolenia z życia (Lin ley, J o s e ph, 2004; U r cu yo i in., 2005; Ogińska-Bulik, 2010c). Szczególnie ważna w kontekście wystąpienia pozytywnych zmian po traumie wydaje się nadzieja. Osoby o wysokim nasileniu nadziei zdają się czerpać więcej korzyści z doświadczeń traumatycznych w porównaniu z jednostkami charakteryzującymi się jej niskim nasileniem. Wskazują na to badania prowadzone przez J. Trzebińskiego i M. Zi iębę (2003), które potwierdziły, że nadzieja podstawowa wiąże się istotnie $\mathrm{z}$ dwoma aspektami potraumatycznego wzrostu, mierzonego Kwestionariuszem Postrzeganych Korzyści, tj. ze wzrostem skuteczności w podejmowanych działaniach i wyższym poziomem duchowości. Podobnie badania prowadzone na grupie ludzi nieodwracalnie okaleczonych (J. Czarnecka, za: Z d a n kiewicz-Śsigała, 2009) dostarczyły danych wskazujących, że osoby o wysokim poziomie nadziei podstawowej uzyskały istotnie wyższe wyniki w zakresie pozytywnego przewartościowania krytycznego wydarzenia. Nadzieja pozwala odnajdować sens życia i znaczenie traumy, na co zwraca uwage K. P o p i els ki (2009). Nadzieja podstawowa pozytywnie koreluje z wynikami polskiej wersji Skali Wzbogacenia Osobistego (Stress-Related Growth Scale), która pozwala ocenić osobowościowe zmiany po traumie $(\mathrm{Zdankiewicz-}$ Ścigała, 2009).

Czynnikiem sprzyjającym wystapieniu pozytywnych zmian po traumie jest optymizm życiowy, choć dostępne w tym zakresie dane nie są jednoznaczne. $\mathrm{W}$ badaniach obejmujących osoby $\mathrm{w}$ żałobie optymizm był pozytywnie skorelowany z potraumatycznym wzrostem (D a v i e s i in., 1998), ale związek ten nie potwierdził się $\mathrm{w}$ grupie rodziców opiekujących się niepełnosprawnym dzieckiem (King i in., 2000). Dodatni związek optymizmu $z$ występowaniem pozytywnych zmian po traumie stwierdzono także w badaniach T. Z o e $11 \mathrm{n}$ er $i$ in. (2008). Sugeruje to, że pozytywny wpływ optymizmu na czerpanie korzyści z traumy może zależeć od rodzaju doświadczonego wydarzenia.

Poczucie koherencji także zdaje się sprzyjać wystapieniu zjawiska, jakim jest potraumatyczny rozwój, choć i w tym przypadku dostępne dane nie są jednoznaczne. Poczucie koherencji przyczynia się do bardziej skutecznego radzenia sobie $\mathrm{z}$ przeciwnościami losu i poznawczego ich przetwarzania (Te de s chi, Calhoun, 1995), dzięki czemu zwiększa szanse na wystąpienie pozytywnych zmian po traumie. Na pozytywny związek poczucia koherencji $\mathrm{z}$ rozwojem po traumie wskazują badania japońskie, przeprowadzone na osobach, które były ofiarami wypadków drogowych (Nishi i in., 2010). Z wynikami SOC korelowały 3 czynniki wchodzące w skład Posttraumatic Growth Inventory, tj. relacje z innymi, nowe możliwości i osobista siła. Z kolei inne badania (Evers i in., 2001) nie potwierdziły związku między analizowa- 
nymi zmiennymi. W badaniach polskich (F e l c y n-K o c ze w s ka, O g ińska-Bulik, 2012) wymiar poczucia koherencji, jakim jest poczucie sensowności, okazał się predyktorem potraumatycznego rozwoju.

Istotnym czynnikiem sprzyjającym wystąpieniu potraumatycznego rozwoju jest właściwość osobowości, określana mianem twardości (hardiness), obejmująca zaangażowanie, kontrolę i postawę charakteryzującą się traktowaniem wydarzeń w kategoriach wyzwania. Pozytywną korelację między zmiennymi potwierdzają badania A. Evers i in. (2001), w których wykazano także pozytywną zależność między poczuciem własnej wartości i skuteczności a występowaniem pozytywnych zmian po traumie. Z kolei wyniki badań prowadzone na kombatantach wojennych i żołnierzach uczestniczących w działaniach wojennych w Wietnamie (D e k el i in., 2004) potwierdziły, że jednostki z wyższym poziomem twardości przejawiały mniej objawów stresu potraumatycznego.

W zakresie poszukiwań podmiotowych uwarunkowań potraumatycznego rozwoju uwzględnia się także prężność. Może ona być rozumiana jako proces (resilience) oraz jako właściwość osobowości lub zasób jednostki (resiliency). Prężność ${ }^{2}$ oznacza $z$ jednej strony zdolność jednostki do oderwania się od przykrych wydarzeń życiowych, a z drugiej - pozwala na bardziej skuteczne radzenie sobie ze stresem i negatywnymi emocjami. Sprzyja ona wytrwałości i elastycznemu przystosowaniu się do wymagań życiowych, ułatwia mobilizację do podejmowania działań zaradczych w trudnych sytuacjach, a także zwiększa tolerancję negatywnych emocji i niepowodzeń. Ponadto osoby odznaczające się wysokim poziomem prężności są bardziej pozytywnie nastawione do życia, przejawiają wyższe poczucie własnej wartości i skuteczności. Jednostka prężna charakteryzuje się stabilnością emocjonalną, napotkane trudności postrzega częściej jako szansę na zdobycie nowych doświadczeń, a siebie skłonna jest uważać za osobę posiadającą wpływ na podejmowanie decyzji (S e mmer, 2006; O g iń sk a-B u lik, J u c z y ń sk i, 2008, 2010a).

Związek między prężnością a potraumatycznym rozwojem nie jest jednoznaczny. Wiąże się to przede wszystkim z różnym rozumieniem prężności (proces, właściwość osobowości). Niektórzy autorzy prężność utożsamiają z potraumatycznym rozwojem (W e s t p h a l, B o n a n n o, 2007). Inni zakładaja, że potraumatyczny rozwój jest pewną formą resiliency (J o h n s o n i in. 2007), jeszcze inni, że potraumatyczny rozwój jest czymś więcej niż prężność i że pełni wobec niej rolę nadrzędną (L e p o re, R e ve n s o n, 2006). Autorzy konstruktu, jakim jest potraumatyczny rozwój (Tedeschi, Calhoun, 1995), wyraźnie różnicują go od resiliency, podkreślając, że rozwój po traumie wynika z trans-

\footnotetext{
${ }^{2}$ Konstrukt prężności został szerzej omówiony w książce Osobowość, stres a zdrowie oraz w artykule Skala pomiaru prężności - SPP-25 autorstwa N. Og ińskiej-Bulik i Z. J u c z y ń s k i e g o $(2008,2010 a)$.
} 
formacji (transformative), co nie dotyczy prężności. Co więcej, podkreślają, że prężne osoby mogą nie doświadczać potraumatycznego rozwoju, ponieważ traumatyczne wydarzenie może nie stanowić dla nich wystarczająco silnego wyzwania. Oznacza to, że prężność i potraumatyczny rozwój to dwa różne zjawiska.

Dla większości badaczy prężność oznacza zdolność przystosowywania się do nowych warunków bez ponoszenia negatywnych konsekwencji w postaci zaburzeń w zakresie życia psychospołecznego. Takie rozumienie konstruktu przyjmują m. in. S. Levin e i in. (2009). Autorzy ci, poszukując zależności między prężnością a potraumatycznym wzrostem, przeprowadzili badania na grupie młodzieży doświadczającej poczucia horroru związanego $\mathrm{z}$ wojną oraz dorosłych - cywili i żołnierzy zaangażowanych w wojnę z Libanem. Za wskaźnik prężności przyjęli zdolność radzenia sobie z traumą bez wykazywania objawów PTSD. Uzyskane wyniki wskazały na istnienie negatywnej zależności między zmiennymi. Im wyższe natężenie resilience, czyli im mniej objawów PTSD, tym niższy poziom pozytywnych zmian po traumie. $Z$ kolei wiadomo, że proces potraumatycznego rozwoju wiąże się z występowaniem objawów PTSD, co więcej, są one traktowane jako warunek pojawienia się wzrostu po traumie.

W badaniach polskich (F e l c y n-K o c z e w s ka, O g ińska-B ulik, 2011; Felcyn-Koczewska, Ogińska-Bulik, 2012), przeprowadzonych na grupie osób, które straciły kogoś bliskiego, wykazano pozytywny związek prężności (traktowanej jako właściwość osobowości) z potraumatycznym rozwojem. Głównym predyktorem pozytywnych zmian po traumie okazał się czynnik 1. prężności, tj. wytrwałość i determinacja w działaniu.

Warto pamiętać, że przedstawione czynniki indywidualne, związane z osobowością jednostki, mogą sprzyjać wystapieniu zjawiska potraumatycznego rozwoju zarówno bezpośrednio, jak i pośrednio, determinując wybór bardziej skutecznych i dostosowanych do sytuacji sposobów radzenia sobie z wydarzeniem traumatycznym.

\section{Potraumatyczny rozwój a zdrowie}

Pojawienie się pozytywnych zmian po traumie jest korzystne dla funkcjonowania człowieka, przede wszystkim z punktu widzenia jego zdrowia zarówno fizycznego, jak i psychicznego. Skuteczne poradzenie sobie z chorobą może zapobiegać nawrotom i zwiększać możliwości radzenia sobie z podobnymi sytuacjami w przyszłości. Wskazują na to badania obejmujące pacjentów kardiologicznych, którzy byli leczeni z powodu zawału serca. $\mathrm{Ci}$, którzy dostrzegali u siebie korzyści z choroby, wykazywali lepszy ogólny stan zdrowia $\mathrm{i}$ byli mniej podatni na ponowny incydent $\mathrm{w}$ postaci zawału serca (A ffle $\mathrm{ck}$ i in., 1987). Wystapienie pozytywnych zmian w wyniku doświadczenia trauma- 
tycznego sprzyja zdrowiu psychicznemu, zwiększa poczucie własnej skuteczności, podnosi samoocenę i zwiększa satysfakcję z życia. Ma to istotne znaczenie dla praktyki. Znając odpowiedź na pytania, kiedy łzy zamieniają się w perły lub dlaczego niektórzy rozkwitają po doświadczeniu traumatycznym, można zwiększyć skuteczność pomocy ludziom, którzy doznali traumy, a także pomagać narażonym na doświadczanie wydarzeń traumatycznych - np. pracownikom służb ratowniczych. Celem terapii powinno być uczenie, jak radzić sobie z jej objawami (a nie, jak ich unikać), uświadamianie ludziom, że negatywne skutki (także w postaci objawów PTSD) mogą służyć przewartościowaniu traumy i prowadzić do rozwoju jednostki. Istotne wydaje się też zapobieganie negatywnym konsekwencjom wydarzeń traumatycznych $\mathrm{w}$ ramach programów prewencyjnych. Powinny one być z jednej strony nastawione na kształtowanie umiejętności radzenia sobie ze stresem, a $\mathrm{z}$ drugiej - na rozwijanie zasobów istotnych $\mathrm{w}$ procesie radzenia sobie.

\section{Ograniczenia i perspektywy}

Zagadnienie potraumatycznego rozwoju wzbudza pewne wątpliwości i kontrowersje. Dotyczą one zarówno samego konstruktu, jak i stosowanych narzędzi pomiaru. Pomimo dość licznych badań w tym zakresie wciąż nie wiadomo, jakie znaczenie dla wystapienia pozytywnych zmian po traumie mają: rodzaj doświadczanego wydarzenia traumatycznego, czas, jaki od niego upłynął, a także ilość doświadczanych zdarzeń. Jak wskazują R. Tedeschi i L. Calhoun (1998, 2007), potraumatyczny rozwój może pojawić się niemal bezpośrednio po doznanym wydarzeniu, jak i wiele lat po jego wystapieniu. Być może czas badania pozytywnych zmian należałoby ograniczyć np. do 5 lat od wystapienia wydarzenia. Umożliwiłoby to porównywanie wyników. Przydatna byłaby także ocena dynamiki zmian w zakresie potraumatycznego rozwoju, co wymagałoby badań o charakterze podłużnym.

Bez odpowiedzi pozostaje pytanie, czy przeżycie kilku traumatycznych zdarzeń pociaga za sobą podobne zmiany, jak doświadczenie jednego. Ponadto, czy potraumatyczny rozwój należy traktować w kategoriach dychotomicznych i mówić o występowaniu zjawiska lub jego braku, czy też raczej, jak postulują R. Tedeschi i L. Calhoun, należy rozważać je w kategoriach nasilenia? Jeśli tak, to jakie należy przyjąc kryteria, na jakiej podstawie wnioskować o niskim, umiarkowanym czy wysokim jego poziomie? W tym celu wskazane byłoby użycie jednolitych narzędzi do oceny pozytywnych zmian, będących skutkiem przeżytego doświadczenia traumatycznego. Czy The Post-Traumatic Growth Inventory, autorstwa R. Tedeschiego i L. Calhouna (1996), oparty na samoopisie, spełnia te oczekiwania? Wielu autorów krytykuje zarówno samą koncepcję, jak i opracowane przez autorów narzędzie pomiaru, ale jednocześnie 
nie ma wśród nich zgodności co do tego, jak mierzyć pozytywne zmiany po traumie. Jedni badacze opowiadają się za pomiarem jakościowym (przeprowadzenie wywiadu), inni za pomiarem ilościowym, dającym możliwości porównań. Jednakże ocena $\mathrm{w}$ kategorii nasilenia (poziomu) pozytywnych zmian dokonywana najczęściej za pomocą skal samoopisowych - wiąże się z wpływem czynników emocjonalno-motywacyjnych, w tym zmienną aprobaty społecznej. Wielu ludzi ma skłonność do przypisywania sobie zmian, pomimo że one nie wystąpiły. Ich deklarowanie może być efektem wyobrażeń, myślenia życzeniowego, iluzji czy służyć podniesieniu samooceny. Niektórzy autorzy, jak np. T. Z o e 11 n e r i A. M a e r cke r (2006), proponują stosować termin ,subiektywne wyobrażenie rozwoju po urazie" (self-perceived posttraumatic growth).

Należy także zwrócić uwagę na wpływy kulturowe dotyczące deklarowanych zmian po traumie, np. w społeczeństwie amerykańskim przypuszczalnie bardziej wyeksponowany jest religijny aspekt potraumatycznego rozwoju (Tedeschi, Calhoun, 2004). Dla zwiększenia obiektywności oceny pozytywnych zmian po traumie przydatne byłyby inne miary, np. oceny dokonywane przez inne - bliskie badanemu - osoby, lub, jak sugerują P. Linley i S. Joseph (2004), ocena reakcji fizjologicznych, dotyczących wydzielania hormonów w odpowiedzi na doświadczenie traumatyczne. Ze względu na wieloczynnikowe uwarunkowania zjawiska potraumatycznego rozwoju wskazane byłyby szersze badania, uwzględniające jednoczesny wpływ zarówno czynników zewnętrznych, jak i podmiotowych. Pomimo przedstawionych wątpliwości oraz kontrowersji, zjawisko potraumatycznego rozwoju przyciaga (i będzie przyciagać) uwagę badaczy i z pewnością będzie przedmiotem wielu badań, zwłaszcza że wyraźnie wpisuje się w spopularyzowany w ostatnich latach nurt psychologii pozytywnej.

\section{Bibliografia}

Affleck G., Tennen H., Croog S., Levine S. (1987), Causal attribution, perceived benefits, and morbidity after a heart attack: An 8-year study, „Journal of Consulting and Clinical Psychology", 55, 29-35.

B u s s e 1 V., N a u s M. (2010), A longitudinal investigation of coping and posttraumatic growth in breast cancer survivors, ,Journal of Psychosocial Oncology”, 28 (1), 61-78.

Calhoun L. G., Tedeschi R. G. (1999), Facilitating posttraumatic growth: A clinican's guide, Lawrence Erlbaum Associates, New Jersey.

C a m p e 11 J. (2007), International Trauma Life Support, Prentice Hall, New Jersey.

Carboon I., A nders on V., Pollard A., S z e r J., S e y mour J. (2005), Posttraumatic growth following a cancer diagnosis: do world assumptions contribute?, „Traumatology”, 11 (4), 269-283.

Carson R. C., Butcher J. N., Mineka S. (2003), Psychologia zaburzeń, vol. 1, GWP, Gdańsk. 
Cordova M. J., Cunnigham L. L C., Carlson C. R., Andrykowski M. A. (2001), Posttraumatic growth following breast cancer: a controlled comparison study, „Health Psychology", 20, 176-185.

D a v i s C. G., N o l e n-H o e k s e m a S. (2001), Loss and meaning. How do people make sense of loss?, „The American Behavioral Scientists”, 44 (5), 726-741.

Davi s C. G., Nol e n-H o e k s e m a S., L a r so n J. (1998), Making sense of loss and benefiting from the experience: Two construals of meaning, „Journal of Personality and Social Psychology", 75, 561-574.

Dekel R., S ol o m on Z., G in zburg K., Z a ki n G., N e ria Y. (2004), Radzenie sobie $w$ sytuacji niewoli wojennej. Wplyw osobowości na zespót stresu pourazowego, [w:] J. S t r e 1 a u (red.), Osobowość a ekstremalny stres, GWP, Gdańsk, 264-280.

Evers A. W., Kraaima t F. W., Lankveld W. van, Jongen P. J., J a cobs J. W., B ij $1 \mathrm{sm}$ a J. W. (2001), Beyond unfavourable thinking: The Illness Cognition Questionnaire for chronic diseases, ,Journal of Consulting and Clinical Psychology”, 69, 1026-1036.

Felcyn-Koczewska M., Ogińska-Bulik N. (2011), Rola prężności w rozwoju potraumatycznym osób w żałobie, [w:] L. G o li ín s k a, E. B i e l a w s k a-B a t o r o w i c z (red.), Rodzina i praca w warunkach kryzysu, Wydawnictwo UŁ, Łódź, 511-524.

Felcyn-Koczewska M., Ogińska-Bulik N. (2012), Psychologiczne czynniki sprzyjajqce wystapieniu potraumatycznego rozwoju u osób $w$ żałobie, [w:] N. O g i ń s k a- B u 1 i k, J. M i n i s z e w s k a (red.), Zdrowie w cyklu życia człowieka, Wydawnictwo UŁ, Łódź, 59-72.

F r e d ri c ks o n B. (2001), The role of positive emotions in positive psychology: The broadenand build theory of positive emotions, „American Psychologist”, 56, 218-226.

Helgeson V., Reynolds K., Tomich P. (2006), A meta-analytic review of benefit finding and growth, ,Journal of Consulting and Clinical Psychology”, 74 (5), 797-816.

Hes zen I. (2010), Duchowość i jej rola $w$ radzeniu sobie ze stresem, [w:] L. S u ch o c ka, R. S z t e m b i s (red.), Człowiek $i$ dzieło, Wydawnictwo KUL, Lublin, 215-223.

H e s z e n I., S ę k H. (2007), Psychologia zdrowia, Wydawnictwo Naukowe PWN, Warszawa.

I s e n A. M. (2005), Pozytywny afekt a podejmowanie decyzji, [w:] M. L e w i s, J. M. H a vi 1 1 a n d-J o n e s (red.), Psychologia emocji, GWP, Gdańsk, 529-549.

Johnson R. J., Hobfoll S. E., Hall B. J., Canetti-N is im D., Galea S., Palmi e r i P. A. (2007), Posttraumatic growth: Action and reaction, „Applied Psychology”, 56, $428-436$.

J o s e ph S., W illi a m s R. (2005), Understanding posttraumatic stress: theory, reflections, context and future, ,Behavioral and Cognitive Psychotherapy”, 33 (4), 423-441.

Kilmer R. P., Gil-Rivas V., Te de s chi R. G., C a nn A., C alhoun L. G., Bu $\mathrm{ch}$ a nan T., Taku K. (2009), Use of the Revised Posttraumatic Growth Inventory for Children, „Journal of Traumatic Stress”, 22 (3), 248-253.

K ing L. A., S c o 11 o n C. K., R a m s e y C., W i 11 i a m s T. (2000), Stories of life transition: Subjective well-being and ego development in parents of children with Down Syndrome, „Journal of Research in Personality”, 34, 509-536.

Le $\mathrm{chn}$ er S. C., A n t o n i M. H. (2004), Posttraumatic growth and group-based intervention for persons dealing with cancer: What have we learned so far?, „Psychological Inquiry”, $15(1), 35-41$.

Lechner S. C., Zakowski S. G., Antoni M. H., Greenhawt M., Block K., B 1 o c k P. (2003), Do sociodemographic and disease-related variables influence benefitfinding in cancer patients?, „Psychooncology”, 12 (5), 491-499.

Lepore S. J., Revenson T. A. (2006), Resiliency and posttraumatic growth recovery, resistance and reconfiguration, [w:] L. G. C a 1 h o u n, R. G. T e d e s c h i (eds.), Handbook of posttraumatic growth: Research and practice, Mahwah, Erlbaum (NJ), 264-290. 
L e vine S. Z., L a u fer A., S te in E., H a m m a-R a z Y., S o 1 o m o n Z. (2009), Examining the relationship between resilience and posttraumatic growth, „Journal of Traumatic Stress”, 22 (4), 282-286.

L in 1 e y P. A., J o s e p h S. (2004), Positive change following trauma and adversity: A review, „Journal of Traumatic Stress”, 17 (1), 11-21.

M c Mille n J. C., S mith E. M., F is h e r R. H. (2001), Perceived benefit and mental health after three types of disaster, „Journal of Consulting and Clinical Psychology”, 65 (5), 733-739.

Mila m J. E. (2004), Posttraumatic growth among HIV/AIDS patients, „Journal of Applied Social Psychology", 34, 2353-2376.

M i 1 a m J. E., R it t-O 1 s o n A., Ung e r J. (2004), Posttraumatic growth among adolescents, „Journal of Adolescent Research”, 19, 192-204.

M o r r i s B., S h a k e s p e a r e-F i n c h J., S c o t t J. (2007), Coping process and dimensions of posttraumatic growth, „The Australian Journal of Disaster and Trauma Studies”, 1, 1-10.

Mystakidou K., Tsilika E., Parpa E., Galanos A., Vlahos L. (2008), Posttraumatic growth in advanced cancer patients receiving palliative care, „British Journal of Health Psychology", 13, 633-646.

Nishi D., Matsuoka Y., Kim Y. (2010), Posttraumatic growth, posttraumatic stress disorder and resilience of motor vehicle accident survivors, „BioPsychoSocial Medicine”, 4 (7) www.bpsmedicine.com/content4/1/7, 20.02.2011.

Ogińska-B ulik N. (2010a), Potraumatyczny rozwój $w$ chorobie nowotworowej - rola prężności, „Polskie Forum Psychologiczne”, 15 (2), 125-139.

O gi ń sk a-B u lik N. (2010b), Doświadczanie sytuacji traumatycznych a zjawisko potraumatycznego rozwoju młodzieży, „Psychologia Rozwojowa”, 15 (3), 33-42.

Ogińska-Bulik N. (2010c), Pozytywne zmiany $w$ nastęstwie doświadczonej traumy zjawisko potraumatycznego rozwoju, [w:] L. S u c h o c k a, R. S z t e m b i s (red.), Człowiek i dzieło, Wydawnictwo KUL, Lublin, 193-203.

O g iń s k a-B u li k N., J u c z y ńs k i Z. (2008), Skala pomiaru prężności - SPP-25, „Nowiny Psychologiczne", 3, 39-56.

O g i ńs k a-B u li k N., J u c z y ński Z. (2010a), Osobowość, stres a zdrowie, Wydawnictwo Difin, Warszawa.

O gińska-B u lik N., Juczy ński Z. (2010b), Rozwój potraumatyczny - charakterystyka i pomiar, „Psychiatria”, 7 (4), 129-142.

O'Le a ry V. E. (1998), Strength in the face of adversity: individual and social thriving Thriving: Broadening the Paradigm Beyond Illness to Health, „Journal of Social Issues”, 54, 425-446.

Park L., Cohen L. H., Murch R. (1996), Assessment and prediction of stress-related growth, „Journal of Personality”, 64, 71-105.

P e n n ebaker J. W. (2001), Uzdrawiająca siła wyrażania emocji, Wydawnictwo ABEDIK, Poznań.

P o 1 a t i n s k y S., E s p r e y Y. (2000), An assessment of gender differences in the perception of benefit resulting from the loss of a child, „Journal of Traumatic Stress”, 13 (4), 709-718.

P o p i e l s k i K. (2009), Psychologia egzystencji. Wartości w życiu, Wydawnictwo KUL, Lublin.

Powell S., Rosner R., Butollo W., Tedeschi R., Calhoun L. G., (2003), Posttraumatic growth after war: A study with former refugees and displaced people in Sarajevo, ,Journal of Clinical Psychology”, 59, 71-83.

S a 1 o J. A., Q o u t a S., P u n a m a k i R. L. (2005), Adult attachment, posttraumatic growth and negative emotions among former political prisoners, „Anxiety, Stress, and Coping”, 18 (4), 361-378. 
Salom o n Z., Dekel R. (2007), Posttraumatic stress disorder and posttraumatic growth among Israeli ex-POWs, ,Journal of Traumatic Stress”, 20, 303-312.

S e m m e r N. (2006), Personality, stress and coping, [w:] M. V o $11 \mathrm{r}$ a th (red.), Handbook of Personality and Health, Wiley, Chichester, 73-113.

S t e e 1 J. L., G a m b 1 i n T. C., C a r r B. I. (2008), Measuring post-traumatic growth in people diagnosed with hepatobiliary cancer: direction for future research, „Oncology Nursing Forum", 35 (4), 643-650.

Tedeschi R. G., Calhoun L. G. (1995), Trauma and transformation: growing in the aftermath of suffering, Sage, Thousand Oakes (CA).

T e d e s c h i R. G., C a 1 h o u n L. G. (1996), The Post-Traumatic Growth Inventory: Measuring the positive legacy of trauma, „Journal of Traumatic Stress”, 9 (3), 455-471.

T e d e s c h i R. G., C a l h o u n L. G. (1998), Posttraumatic growth: future directions, [w:] R. G. Te d e s c hi, C. L. P a r k, L. G. C a 1 h o u n (eds.), Posttraumatic Growth: Positive Changes in the Aftermath of Crisis, Lawrence Erlbaum Associates Publishers, New York, 215-238.

T e d e s c h i R. G., C a 1 h o u n L. G. (2004), Posttraumatic growth: Conceptual foundations and empirical evidence, ,Psychological Inquiry”, 15, 1-8.

T e d e s c h i R. G., C a 1 h o u n L. G. (2007), Podejście kliniczne do wzrostu po doświadczeniach traumatycznych, [w:] P. A. L in 1 e y, S. J o s e p h (red.), Psychologia pozytywna w praktyce, Wydawnictwo Naukowe PWN, Warszawa, 230-248.

T e n n e n H., A f fl e c k G. (2002), Benefit-finding and benefit-reminding, [w:] C. R. S n y d e r, S. J. L o p e z (eds.), The handbook of positive psychology, Oxford University Press, New York, 584-597.

T e o C. K., T e o I. E., B eng I m-T e o C. (2007), Posttraumatic growth in cancer: perspectives of Indo-Malaysian patients, „The Internet Journal of Family Practice”, 5 (1), $3-13$.

Trzebiński J., Zięba M. (2003), Kwestionariusz nadziei podstawowej - BHI-12. Podręcznik, Pracownia Testów Psychologicznych Polskiego Towarzystwa Psychologicznego, Warszawa.

Urcuyo K. R., B oyers A. E., Carver C. S., A n ton i M. H. (2005), Finding benefit in breast cancer: Relations with personality, coping, and concurrent well-being, „Psychology and Health", 20, 175-192.

W e is s T. (2002), Posttraumatic growth in women with breast cancer and their husbands: An intersubjective validation study, ,Journal of Psychosocial Oncology”, 20, 65-80.

Westphal M., Bonanno G. A. (2007), Posttraumatic growth and resilience to trauma: Different sides of the same coin or different coins?, „Applied Psychology”, 56, 417-427.

$\mathrm{Z}$ a ł u s k i M. (2008), Rozwojowe zmiany po doświadczeniach na misjach wojskowych. Doniesienie z badań, „Sztuka Leczenia”, 3-4, 95-115.

Z d a n k i e w i c z-Ś c i g a ł a E. (2009), Nadzieja podstawowa jako moderator procesu adaptacji po traumie, [w:] J. S tre la u, B. Z a w a d z ki, M. K a c z ma r e k (red.), Konsekwencje psychiczne traumy. Uwarunkowania i terapia, Wydawnictwo Naukowe SCHOLAR, Warszawa, 132-153.

Z o e $11 \mathrm{n}$ e r T., M a e r c k e r A. (2006), Posttraumatic growth in clinical psychology-A critical review and introduction of a two component model, „Clinical Psychology Review”, 26, 626653.

Z oe 11 ne r T., R a be S., K a r 1 A., M a e r c ke r A. (2008), Posttraumatic growth in accident survivors: openness and optimism as predictors of its constructive or illusory sides, „Journal of Clinical Psychology”, 64 (3), 245-263. 
Nina Ogińska-Bulik

\section{When tears change into pearls - or about benefits resulting from a struggle with trauma}

The article presents posttraumatic growth phenomena, which was introduced by Tedeschi and Calhoun to identify positive changes experienced as a result of struggle with trauma. These changes include a greater sense of one's personal strength, increased relations to others, a changed philosophy of life, such as greater appreciation for life, and spiritual growth.

The concept, epidemiology, and first of all determinants of posttraumatic growth are presented, among them external factors - related to trauma, such as intensity of traumatic events, the intensity of negative outcomes (such as level of PTSD), and individuals factors, among them coping strategies and personality features (such as optimism, sense of coherence, self-esteem, self-efficacy, resiliency) of subject who have experienced trauma.

Keywords: posttraumatic growth, trauma, coping with stress, personal resources, social support (rozwój potraumatyczny, trauma, radzenie sobie ze stresem, zasoby osobiste, wsparcie społeczne). 